9. Nkondjock, A., Shatenstein, B., Maisonneuve, P. (2003). Specific fatty acids and human colorectal cancer: an overview. Ghadirian Cancer Detect Prev, 27 (1), 55-62. doi: 10.1016/s0361-090x(02)00179-4

10. Official Journal of the European Union L276/33 (2010). Directive 2010/63/EU OF the european parliament and of the council of 22 September 2010 on the protection of animals used for scientific purposes. 86/609/EC. 20.10.2010.
11. Folch, J., Lees, M., Stauley, G. (1957). Asimple method for the isolation and purification of total lipids fromanimal tissues. J. Biol. Chem., 226, 497.

12. Vlizlo, V. V., Fedoruk, R. S., Ratych, I. B. et al. (2012). Laboratory methods of investigation in biology, stockbreeding and veterinary. Reference book ; Edited by V. V. Vlizlo. Lviv : SPOLOM, 764. [in Ukrainian].

Рекомендовано до публікаиії д-р біол. наук, професор Малик О. Г. Дата надходження рукопису 31.10.2014

Грабовський Степан Стефанович, кандидат біологічних наук, кафедра біологічної та загальної хімії, Львівський національний університет ветеринарної медицини та біотехнологій імені С. З. Гжицького, вул. Пекарська, 50, Львів, 79010, Україна,

E-mail: grbss@ukr.net

Грабовська Олександра Степанівна, кандидат біологічних наук, Лабораторія інтелектуальної власності та маркетингу інновацій, Інститут біології тварин НААН, вул. В. Стуса, 38, м. Львів, 79034, Україна E-mail: alice_grb@ukr.net

Пилипець Андрій Зіновійович, кандидат сільськогосподарських наук, Лабораторія інтелектуальної власності та маркетингу інновацій, Інститут біології тварин НААН, вул. В. Стуса, 38, м. Львів, 79034, Україна

E-mail: alice_grb@ukr.net

УДК: 167.33:616.36-004+599.323.41

DOI: 10.15587/2313-8416.2014.29151

\title{
МОДЕЛЮВАННЯ ТОКСИЧНОГО ПОШКОДЖЕННЯ ПЕЧІНКИ НА ЛІНІЇ МИШЕЙ ICR
}

\author{
(C) М. В. Драгулян, Т. П. Гулько, В. А. Кордюм, Р. В. Бубнов, О. Г. Дерябіна
}

\begin{abstract}
Цироз печінки є важким ускладненням хвороби печінки. Використання тварин із синтетично індукованим 30 \% масляним розчином CCl4 ураженням печінки дає можливість більш глибше та доскональніше вивчати морфологічні та функиіональні зміни иього органу. Використовуючи біохімічні, иитологічні, гістологічні, рентгенологічні та морфометричні методи нами було встановлено, що в печінці експериментальних самиів-мишей лінії ICR з модельним пошкодження печінки спостерігаються глибокі зміни з подальшим розвитком незворотних новоутворень.

Ключеві слова: миші лінії ICR, печінка, некроз, фіброз, цироз, новоутворення,CCl4, АЛТ, АCT, УЗД.
\end{abstract}

Cirrhosis is severe complications of liver disease. Using animals with synthetically induced $30 \%$ oil solution of CCl4-induced liver injury enables deeper study morphological and functional changes of the body. Using biochemical, cytological, histological, radiological and morphometric methods, we have found that profound changes with subsequent development of irreversible tumors are observed in the liver of experimental male-ICR mice with a model of liver damage.

Keywords: ICR mice line, liver, necrosis, fibrosis, cirrhosis, cancer, CCl4, ALT, AST, ultrasonic diagnostics.

\section{1. Вступ}

Цироз печінки - хронічне захворювання печінки, для якої характерне значне зменшення маси функціонуючих гепатоцитів і яке супроводжується порушенням іiі функціональної діяльності. Цьому захворюванню передує запалення печінки, фіброз печінки [1]. Найчастіше ця хвороба вражає людей 3 послабленим імунітетом, які хворіли на різні інфекційні захворювання (наприклад гепатит). Досі залишається невивченою зона ризику набутих хвороб печінки (гепатит, фіброз, цироз) у людей, які мають схильність до раку молочної залози (є фактом, що рак викливається вірусом). Залишається невивченим питання, щодо ймовірності не тільки набути хвороби печінки, а й можливості розвитку раку печінки - гепатоцерулярної карциноми [2]. Захворювання печінки зазвичай має тривалий перебіг, без клінічних симтомів. Важлива причина хвороби - тривале ведення токсинів, що ослаблює мембрану гепотоцитів. Послаблена мембрана чутлива для проникненню кальцію. Кальцій накопичується у клітині та пошкоджує іiі нормальне функціонування:збільшує кількість прозапальних цитокинів, що активують Купферовські клітини на виробку колагену II типу [3]. В результаті утворюється сполуно-тканинний тяж або септа. Створення ефективної моделі захворювання на тваринах, а саме на гризунах, дає можливість підвищити ефективність лікування уражень печінки у людей. 
Існує багато способів моделювання уражень печінки у гризунів [4, 5]. При цьому розвиток порушення функціональної діяльності печінки від різних стадій фіброзу до кінцевої стадії - цирозу відбувається з різною швидкістю, залежно від дози хімічного реагенту, який визиває ураження печінки (нами використовувався $\mathrm{CCl} 4$ ), віку та лінії мишей.

Метою було дослідження гістологічної, морфологічної характеристик експериментальної моделі ураження печінки мишей.

\section{2. Огляд літератури}

Iз багаточисленних моделей одні методи спрямованні на отримання тільки захворювань печінки, інші ж- на отримання системного пошкодження внутрішніх органів організму. I ті і інші безумовно викликають цікавість, і використовуються залежно від поставленого завдання

Хронічні стадії хвороби печінки призводять до так званого гепаторенального синдрому, тобто патологія печінки, призводить до патології нирок. Тому, безумовно серед системних моделей пошкодження внутрішніх органів цікавою $\epsilon$ експериментальна модель токсичної нефропатії та цирозу печінки 3 використанням совтола-1 [6]. Російський вчений Мишкін В. А. на білих щурах вагою 180-230 гр. отримує протягом 30 днів системну модель шляхом внутрішньо шлункового введення 2 рази на тиждень 150 мг совтола-1 (на 100 г ваги), розчиненого в оливковій олії [7].

Для досягнення комплексної моделі пошкоджень внутрішніх органів, що спричинена цирозом печінки, часто використовують хірургічні втручання. Так, самцям щурів лінії Wistar, вагою 160-220 гр для отримання цирозу печінки роблять перев'язку загального жовчного протоку в нижній треті капроновою лігатурою. Пошкодження печінки спостерігаються на 14 добу, а на 30 добу відзначаються дистрофічні зміни у нирках [8].

При моделюванні пошкоджень печінки наряду iз хірургічними методами використовують i бактеріологічні. Наприклад, вчені із інституту імунології МЗ РАМН РФ при моделюванні гострого гнійного холангіту перев'язували ділянку загального жовчного протоку, але перед цим заздалегідь вводили катетер, по якому вводилась суспензія E. coli штам №196 в концентрації 0.95 х 10 КОЕ в 1 мЛ (0.4 мл/кг ваги) [9].

Виходячи із того, що намагаються дослідити автори, модель викликається тим, чи іншим способом. Наприклад, Tung_Ming Leung, вивчаючи ендотеліальний синтез оксиду азоту, як важливого фактору при експериментальному фіброзі печінки, проводив свої дослідження на восьмитижневих білих лабораторних мишах, викликаючи захворювання 7 способами: першій довали тетрахлорид вуглеводу (CCl4 50 мкл/кг); другій групі - D-аргінін (200 мг/кг); третій - D-аргінін+ CCl4; четвертій - метілізотіомочевини гемі сульфат (SMT, 10 мг/кг); п'ятій L-аргінін (200 мг/кг); шостій - SMT + CCl4; сьомій $\mathrm{L}$-аргінін+ $\mathrm{CCl}$. $\mathrm{CCl} 4$ розчиняли в олівковій олії та вводили 2 рази на тиждень внутрішньочеревним способом [10]. Викликали захворювання печінки 8 тижнів. Найшвидше захворювання виявлялось у першій групі, якій вводили CCl4.

Слід відмітити, що найчастіше і на мишах, i на крисах для отримання моделей пошкодження печінки використовують чотирьох хлористий вуглевод (CCl4), який у різних концентраціях та за різною періодичністю введення внутрішньочеревним способом, має здатність викликати гепатит, фіброз, цироз та гепатоцерулярную карциному. Механізми цитотоксичності CCl4 обумовлені тим, що ця речовина має властивість достатньо легко розпадатися до вільних трихлорметильних радикалів. А в основі токсичної дії лежить пошкодження клітин, що супроводжується їх функціональними чи структурно-функціональними змінами, такими як: пошкодження енергетичного обміну, пошкодження гомеостазу внутрішньоклітинного кальцію, активація вільно-радикальних процесів у клітині, порушення процесів синтезу білку та клітинного поділу, пошкодження клітинних мембран [11]. Необхідно відмітити, що усі ці механізми тісно взаємопов'язані між собою. Інколи один із них є пусковим, але в подальшому особливу роль для долі пошкодження клітини набувають інші механізми.

На щурах дослідниками із Азейбарджана було отримано модель печінкової інтоксикації, яка була викликана на самцях масою 18-200 гр. шляхом внутрішньочеревної ін'єкції CCl4 (150 мкг/100гр ваги тварини) [12]. На щурах також працювали російські вчені, що викликали гостре токсичне ураження на самцях вагою 280-340 гр. 50 \% масляним розчином CCl4. Щурам кожного дня шляхом внутрішньочеревної ін'єкції вводили 0,4 мл. розчину та вже через 7 діб отримали модель гострого токсичного ураження печінки [5].

Проте способи введення CCl4 у організм тварини є різі. Наприклад, дослідники із інституту цитології РАН вводили CCl4 інгаляційним шляхом (7 мл на 100 л) самцям щурів масою 130-140 г протягом 6 місяців один раз на тиждень протягом 30 хв [4]. Ті ж самі дослідники зробили ще одне спостереження якщо викликати цироз у щурів вагою 300-350 гр. протягом 6 місяців, то кількість інгаляцій збільшується до 3 разів на тиждень, а час однієї інгаляції зменшується з 30 хвилин до 20 хвилин [13].

Цікавим фактом $є$ те, що CCl4 використовують не тільки на моделі in vivo, але й на моделі in vitro [14]. Саме на таких моделях in vitro вивчають молекулярні механізми всередині клітини. Хоча найчастіше модель отримують in vivo, а потім отримують ізольовані гепатоцити. Так, наприклад Е. В. Байдюк и др. отримують модель токсичного гепатоциту на самцях щурів вагою 180-200 гр. шляхом інтрагастрального введення упродовж 4 тиж $50 \%$ розчину $\mathrm{CCl} 4$ у вазеліновому маслі в дозі 0,2 мл/кг, а як добавку під час пиття додавли $5 \%$ етанол, а потім за методом Селгена розпускали гепатоцити, щоб порівняти морфофункціональні особливості здорових гепатоцитів та гепатоцитів із печінки ураженої токсичним реагентом [15].

Але мишка - об'єкт набагато менший, ніж щур, і такі методи, як хірургічний чи інгаляційний 
дуже важко відтворити, тому частіше використовують внутрішньочеревну ін'єкцією. Досліджуючи трансформуючий ростовий фактор Н. А. Джояшвили визивав фіброз печінки на мишах-самцях лінії $B A L B$ внутрішньочеревну ін'єкцією $30 \%$ масляного розчину CCl4 (із розрахунку 1 мкл/1 г маси тіла) 1 раз на тиждень. Через 4 тижні ним було отримано фіброз печінки, а через 6 тижнів - цироз [16].

Проаналізовані дані дають можливість розрахувати кількість введення $\mathrm{CCl} 4$, виходячи із віку та ваги тварин, а періодичність та тривалість введення залежить від кінцевої мети. Нами на 3-місячних самцях мишей лінії ICR вивченні морфологічні характеристики процесів власної регенерації, компенсації. Пошкодження печінки викликали 30 \% олійним розчином CCl4 (1мкл на 1г ваги) шляхом внутрішньочеревної ін'єкції 1 раз на тиждень протягом 7 тижнів. Стан печінки та інших внутрішніх органів свідчив про наявність фіброзу печінки. Але вже через 6 тижнів після припинення введення токсину за рахунок власних регенераційних процесів встановлюється внутрішній баланс, який призводить до часткового відновлення пошкодженої паренхіми [17]. Але жодна тварина не мала достатньої патології, яка б свідчила про розвиток новоутворення, тому актуальним залишається збільшення дози, часу та періодичності введення CCl4.

\section{3. Матеріали та методи дослідження}

Дослідження виконували у відділі «Регуляції механізмів клітини» інституту молекулярної біології та генетики НАН України.

Дослідження проведені на 50 мишах-самцях лінії $I C R$, які на початку експерименту були розділені на 2 групи тварин. Тваринам першої групи (дослідні) на протязі всього експерименту 2 рази на тиждень внутрішньочеревним способом вводили 30 \% масляний розчин CCl4 (1,5 мкл на 1 г тварини). Тваринам другої групи (контрольні) на протязі всього експерименту 2 рази на тиждень внутрішньочеревним способом олію 2 рази на (1,5 мкл на 1 г тварини). На початку експерименту маса тіла мишей, яких утримували на стандартному харчовому раціоні становила 20-23 г.

Тварин після проведення УЗД внутрішніх органів і попереднього нічного голодування виводили з екперімента на 2, 4, 6, 8 тижні досвіду. Отриманий матеріал використовували для проведення патологоанатомічних, біохімічних, гістологічних досліджень.

Опис анатомічного та фізіологічного стану органів досліджуваних мишей. Діагностичний алгоритм базувався на основі візуальної оцінки кольору, розміру, форми країв і консистенції органу. Оцінювалася зернистість i наявність фіброзних включень. Крім цього, фіксували вагу печінки, нирки, легенів, тімуса та селезінки, розрахунку на 100 г ваги тварини.

Цитологічні методи дослідження. Мазки робили за допомогою шліфованих скелець на чистих знежирених предметних скельцях. Для фіксації використовували метод Май-Грювальда, фарбували способом Романовського.
Біохімічні методи дослідження. Визначення аланінамінотрансферази (АЛТ) i аспартатамінотрансферази (АСТ) в сироватках крові мишей контрольної та дослідних груп визначали за допомогою фотоелектроколориметра КФК-2, основний принцип дії якого полягає у визначенні оптичної щільності розчини i концентрації речовини, що аналізуємо. Для визначення активності амінотрансфераз використовували тест системи виробника Audit Diagnostics (Ireland).

Ультразвукове дослідження внутрішніх органів мишей. Важливим критерієм для оцінки розвитку захворювання печінки при проведенні УЗД на мишах служили показники зміни розміру печінки, розміру селезінки, діаметра ворітної вени.

Гістологічні методи дослідження. Шматочки печінки мишей фіксували в 10 \%-ому нейтральному формаліні, заливали в парафінові блоки, 3 яких приготовляли зрізи товщиною близько 5 мкм. Зрізи тканини фарбували гематоксиліном-еозином за Романовським.

Статистичну обробку результатів, яка включала в себе аналіз достовірності відмінностей середніх величин за критерієм Стьюдента, проводили за допомогою програми MC Exel

\section{4. Результати досліджень}

Вивчення впливу в/ч ін'єкції 35 мкл 30 \% CCl4 2 рази на тиждень при моделюванні глибокого пошкодження печінки було розпочато у сприятливий осіньо-зимовий період. На початку досліду здорові тварини мали фізіологічні параметри внутрішніх органів. Біохімічні показники АЛТ та АСТ на 0 точці дослідження не перевищували 20 Од/л. В минулих дослідах на 3 місячних самцях мишей лінії $I C R$, відмічено, що ці показники у здорових тварин не перевищували 25 Од/л [17]. Гістологічне досліджен-ня на початку досліду у межах норми: стан стінок центральних вен також у нормі. Візуалізується розширення перисуносного склерозу центральних вен соїдального простору Дісе, що варіює від слабкого до чітко вираженого. Балочно-радіальна будова печінкових дольок збережена та чітко виявляється. Стан портальних трактів: не розширені, без ознак склерозу та запалення (рис. 1).

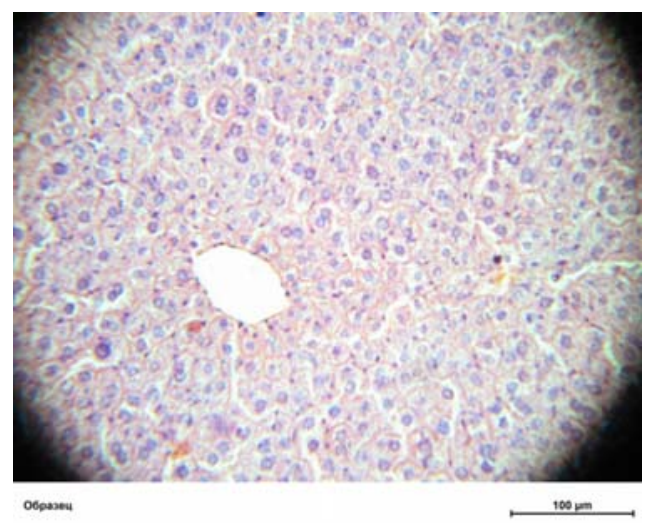

Рис. 1. Гістологія печінки здорової мишки

На початку дослідження лейкоцитарна форма складається: із лімфоцитів (в середньому 64 \%), 
сегментоядерних нейтрофільних (СЯ) гранулоцитів (в середньому $26 \%$ ), паличко ядерних (ПЯ) нейтрофільних гранулоцитів (в середньому 9 \%) та моноцитів (в середньому 1 \%) (табл. 1).

Таблиця 1

Динаміка змін формових елементів крові мишей лінії ICR під дією CCl4

\begin{tabular}{|l|c|c|c|c|c|}
\hline \multirow{2}{*}{ Формені елементи крові } & \multicolumn{4}{|c|}{ Тиждень дослідження } & $\begin{array}{c}\text { Контрольна група } \\
\text { тварин }\end{array}$ \\
\cline { 2 - 6 } & 0 & 4 & 6 & 8 & 0 \\
\hline Еозінофіли, \% & 0 & 0 & $3,0 \pm 0,0$ & $2,5 \pm 0,5$ & $2,0 \pm 0,0$ \\
\hline Базофіли, \% & 0 & 0 & $4,0 \pm 0,0$ & $4,5 \pm 0,5$ & $5,5 \pm 0,5$ \\
\hline ПЯ гранулоцити, \% & $9,0 \pm 0,0$ & $9,0 \pm 0,0$ & $8,5 \pm 0,5$ & $9,0 \pm 0,0$ & $19,0 \pm 0,0$ \\
\hline СЯ гранулоцити, \% & $26,0 \pm 0,0$ & $47,0 \pm 0,0$ & $37,5 \pm 0,5$ & $37 \pm 0,0$ & $67,5 \pm 0,5$ \\
\hline Лімфоцити, \% & $64,0 \pm 0,0$ & $42,0 \pm 0,0$ & $43,0 \pm 0,0$ & $43,0 \pm 0,0$ & $2,0 \pm 0,0$ \\
\hline Моноцити, \% & $1,0 \pm 0,0$ & $2,0 \pm 0,0$ & $3,0 \pm 0,0$ & $3,5 \pm 0,5$ & \\
\hline
\end{tabular}

На 4-тому тижні дослідження печінка набуває візуальних змін: змінюється колір до темнобардового кольору, края печінки загострюються, за консистенцією орган стає неоднорідним. Змін також зазнають легені: змінюється колір до сіроваторожевого, за консистенцією орган стає пузирчастим.

Вага внутрішніх органів також набуває змін: збільшується вага печінки (рис. 2), збільшується вага легень (рис. 3), збільшується вага селезінки (рис. 4).

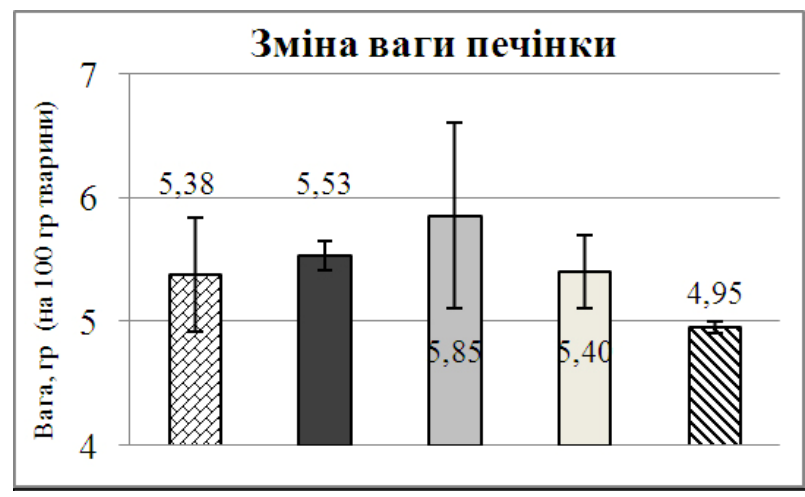

Рис. 2. Зміна ваги печінки при моделюванні пошкодження печінки в/ч ін'єкцією 2 рази на тиждень 35 мкл 30 \% CC14: експерименту; |-4 тижні експерименту;| |-6 тижнів експерименту; $\mathbb{\mathbb { N }}-8$ тижнів експерименту

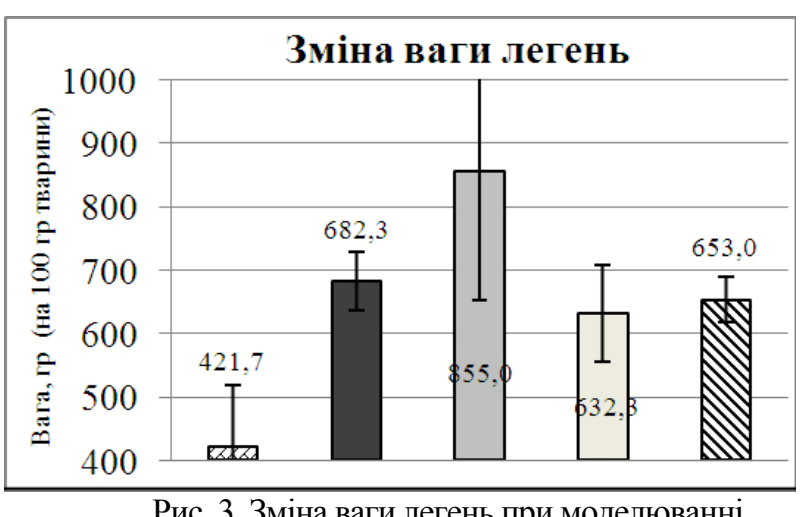

Рис. 3. Зміна ваги легень при моделюванні пошкодження печінки в/ч ін'єкцією 2 рази на тиждень 35 мкл 30 \% CCl4: 学 - контроль; | - 0 тижнів експерименту; |-4 тижні експерименту;| |-6 тижнів експерименту; $\mathbb{E}$-8 тижнів експерименту

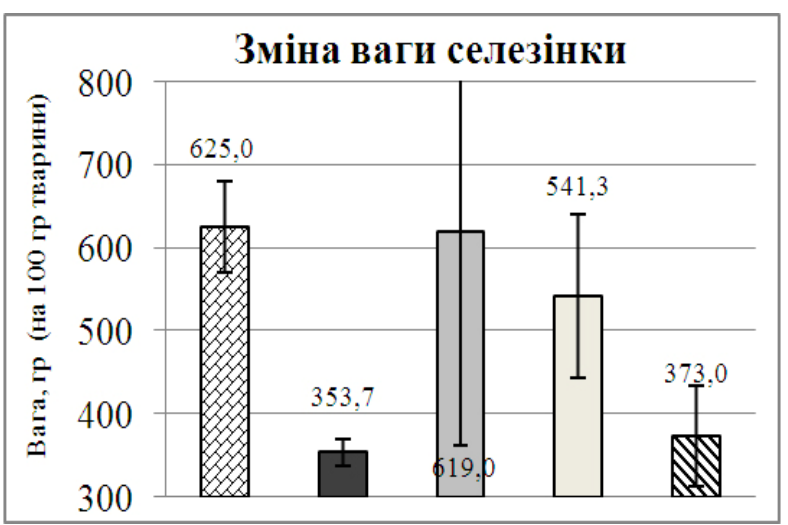

Рис. 4. Зміна ваги селезінки при моделюванні пошкодження печінки в/ч ін'єкцією 2 рази на тиждень 35 мкл 30 \% CCl4:

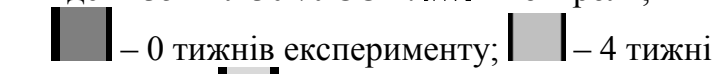
експерименту;
- 8 тижнів експерименту

Майже у 4 рази збільшується біохімічні показники (рис. 5). Переважає активність АСТ над АЛТ, що може свідчити про макроцитоліз еритроцитів та гепатоцитів [10, 18].

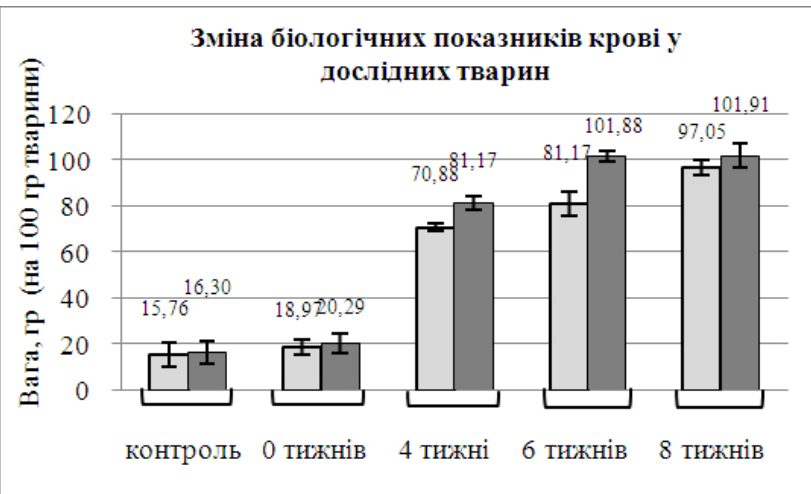

Рис. 5. Зміна біохімічних показників крові при моделюванні пошкодження печінки в/ч ін'єкцією 2

рази на тиждень 35 мкл $30 \% \mathrm{CCl} 4: \mid$ - АЛТ;

$$
\text { 1-ACT }
$$

Гістологічний аналіз печінки виявив порушення балочно-радіальної будови дольок за 
рахунок наявності крупних ділянок некрозу тканини. Ділянки тканини печінки 3 явно вираженим відкладанням гомогеної аморфної блідо-рожевої речовини між печінковими балками. Деякі ділянки гепатоцитів у стані некрозу. Інші гепатоцити у стані білкової дистрофії з ознаками деформації (рис. 6, a).

Динаміка змін лейкоцитарної форми свідчить про наявність запальної реакції, яка проявляється в збільшенні відсотка сегментоядерних нейтрофільних гранулоцитів із $26 \%$ до $47 \%$ (табл. 1). У людей з алькогольним ураженням печінки на ранніх етапах розвитку цирозу печінки також відмічається наявність запальної реакції та збільшення СЯ гранулоцитів [19]. А при моделюванні цирозу печінки на щурах лінії Wistar шляхом в/ч інєкції 30 \% масляного розчину $\mathrm{CCl} 41$ раз на тиждень такого різкого запального процесу нами не було відмічено [20]. Можливо, доза та періодичність введення $30 \%$ CCl4 вплинули на швидкий та інтенсивний запальний процес.

На 6 тижні дослідження спостерігається зменшення ваги печінки (рис. 2), яке супроводжується зміною кольору органу (печінка стає світло-бардового кольору) та появою на всіх долях печінки зернистості. При цьому незначні зміні спостерігаються і в вазі селезінки та легень (рис. 3, 4). Активність трансамілаз збільшується та зберігається перевага АСТ над АЛТ (рис. 5). Гістологічне дослідження свідчить про відсутність балочно-радіальної будови, в наслідок масштабного некрозу печінки. Присутня жирова дістрофія гепатоцитів. Місцями гепатоцити стоншені, майже до повної їх атрофії. В стромі органу лімфоцитарная інфільтрація. Наявні очаги некрозів із розростанням сполучної тканини. Візуалізуються ділянки печінки 3 відкладенням блідо-рожевої речовини (рис. 6, б).

На фоні вираженого запального процесу з'являються ознаки алергічної реакції збільшується відсоток еозинофілів та базофілів (табл. 1).

Нажаль, явні клінічні особливості різних форм захворювання печінки відсутні, що не дає змогу провести діагностику. Але через 2 місяці від початку дослідження візуально на печінці виникають новоутворення. Вони можуть бути як поверхневими, так і пронизувати паренхіму органа. Колір новоутворень від блідо-рожевого до блідожовтого кольору. За консистенцією новоутворення є твердими.

Сильно страждають нирки. Гістологічно зміни у нирках свідчать про наявність помірного аутоліза. Стінки судин неравномірно склеротично потовшені. Виявлені лімфоцитарні інфільтрати в строму органу. Невелика кількість канальців Шумлянського Боумена 3 кістозними розширеннями, які заповнені гомогеним рожевим колоїдноподібним вмістом (рис. 7).

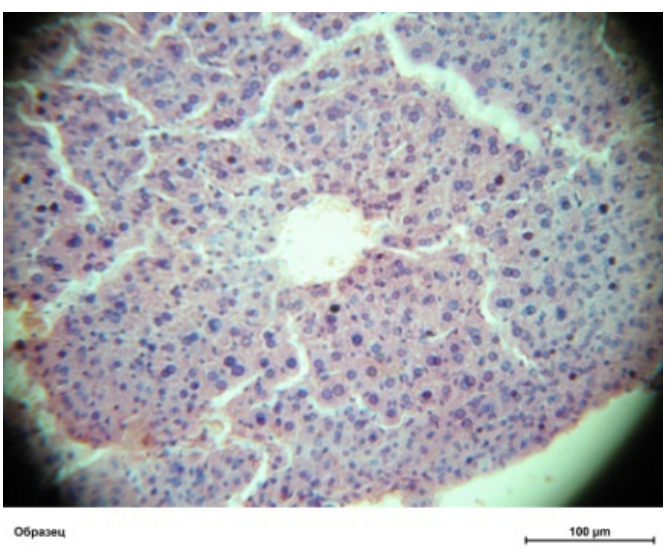

$a$
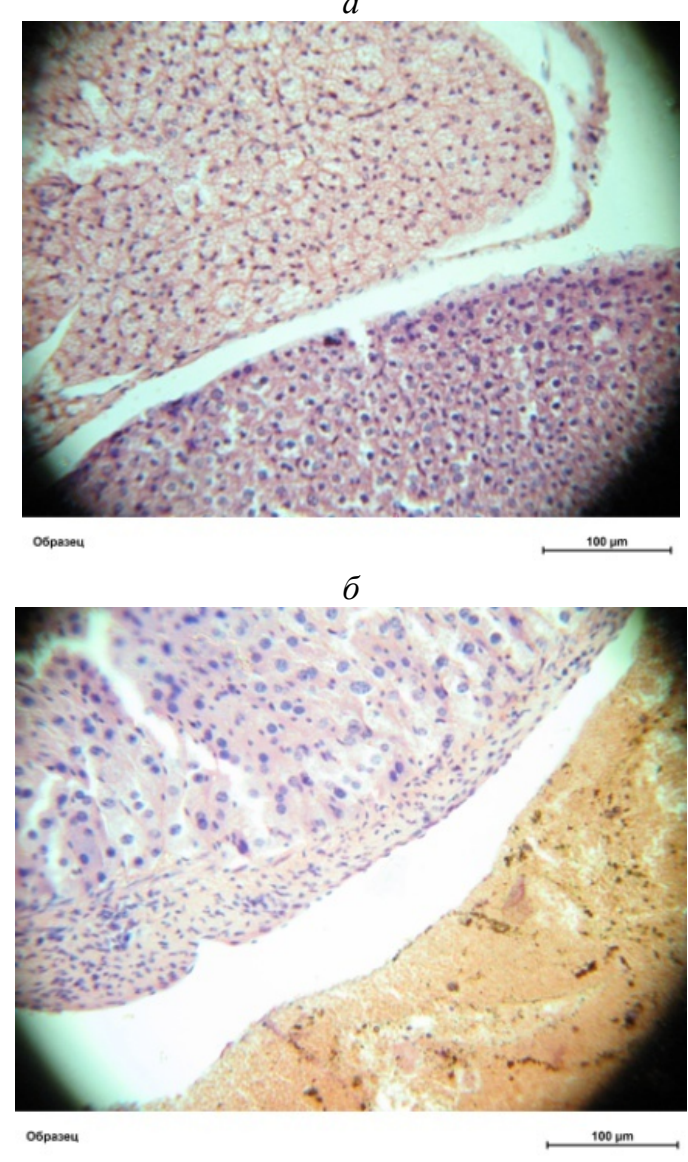

B

Рис. 6 Динаміка гістологічних змін в печінці при дії на організм 30 \% CCl4: а - через 4 тижні;

б - через 6 тижнів; в - через 8 тижнів

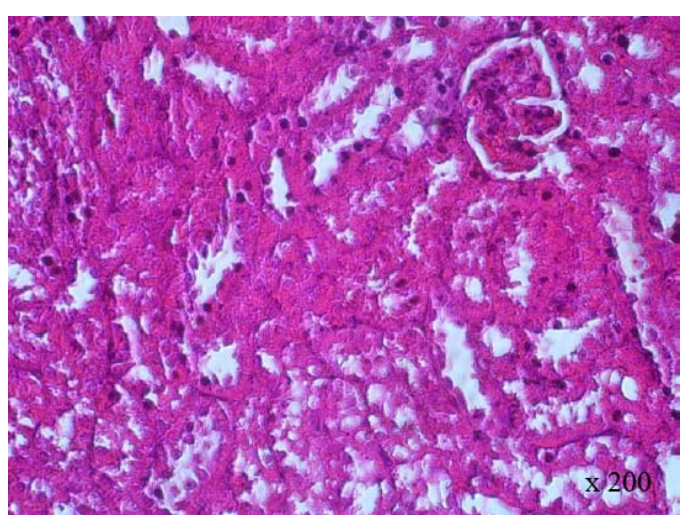

Рис. 7. Гістологія нирок мишей після 8 тижнів введення $30 \% \mathrm{CCl} 4$ 
Печінка гістологічно не має балочнорадіальної будови через масштабний некроз. Цитоплазма гепатоцитів зернистого виду, без ознак жирової дістрофії. Велика кількість гепатоцитів некратизована. Портальні тракти розширені, в їх стромі лімфоцитарна інфільтрація. Наявні ділянки некрозу 3 розрастанням сполучної тканини. Візуалізуються ділянки з відкладенням блідо-рожевої речовини (рис. 6, в). При проведенні УЗД печінки у дослідних мишей розмір печінки був 1,2 см, діаметр воротної вени 0,14 см. У контрольних тварин розмір печінки та діаметр воротної вени був 1,3 та 0,09 см відповідно. Інші маркерні дослідження також підтверджують прогресуюче захворювання.

В результаті нами була отримана модель пошкодження печінки, яка 3 часом призводить до пошкоджень інших внутрішніх органів. Сама печінка набуває суттєвих змін, що проявляються в виникненні новоутворень (рис. 8).
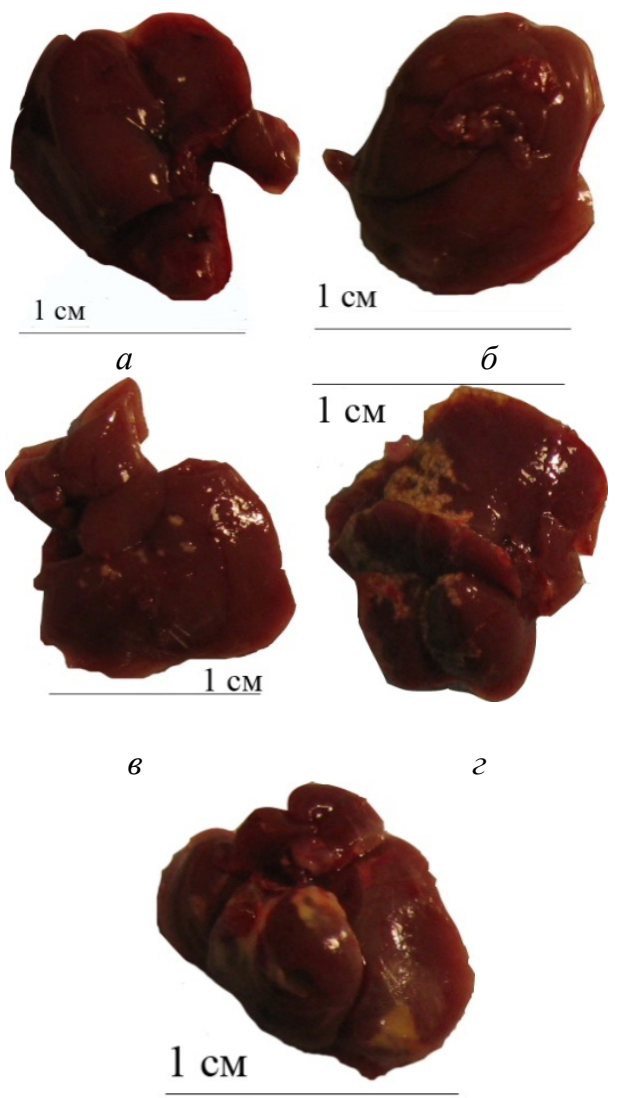

$\partial$

Рис. 8. Дінаміка виникнення новоутворень у мишей лінії ICR під дією 30 \% CC14: $a$ - контроль;

$\sigma$ - о точка дослідження; в - 4 тижні введення 3

$0 \% \mathrm{CCl} 4 ; 2-6$ тижнів введення $30 \% \mathrm{CCl} 4$; $\partial-8$ тижнів введення $30 \% \mathrm{CCl} 4$

При внутрішньочеревному введеню піддослідним мишам 2 разів на тиждень напротязі 2 місяців $30 \%$ масляного розчину $\mathrm{CCl} 4$ із разрахунку 1,5 мкл на 1 г маси тіла нами було отримано глубоке пошкодження печінки, яке викликало пошкодження i в інших внутрішніх органах. Характерною ознакою цього пошкодження печінки було виникнення новоутворень, що мали різний колір та локалізацію на долях органу. Окрім того було виявлено ознаки, що характерні для фіброзу печінки, про що свідчать збільшені показники АЛТ, АСТ, гістологія печінки та результати УЗД.

\section{5. Висновки}

У самців мишей лінії ICR 3-х місячного віку в результаті отруєння $30 \%$ масляним розчином $\mathrm{CCl} 4$ шляхом в/ч ін'єкції 2 рази на тиждень протягом 8 тижнів виникає захворювання печінки, що за вивченими маркерами схожий 3 фіброзом печінки, але із виникненням новоутворень. Динаміка виникнення захворювання печінки свідчить, що чим глибше захворювання печінки, тим більше та глибше пошкоджуються інші внутрішні органи. В подальшому планується залучати цю модель в розробках методів лікування хворих, які мають схильність до раку молочної залози, чи у людей, які вже мають хворобу (хвороби) печінки із новоутворенням.

\section{Література}

1. Бабак, О. Я. Проблема фиброгенеза неалкогольной жировой болезни печени [Текст] / О. Я. Бабак // Сучасна гастроентерологія. - 2007. - № 4 (36). - С. 4-10.

2. Лазаревич, Н. Л. Молекулярные механизмы прогрессии опухолей печени [Текст] / Н. Л. Лазаревич // Успехи биологической химии. - 2004. - Т. 44. - С. 365-418.

3. Бабак, О. Я. Механизмы гепатопротекторного и токсического влияния азота оксида [Текст] / О. Я. Бабак, Н. В. Ярмыш, Г. Ю. Панченко // Сучасна гастроентерологія. - 2006. - № 5 (31). - С. 76-84.

4. Безбородкина, Н. Н. Морфометрия митохондриального апарата гепатоцитов нормальной и цирротически измененной печени крыс [Текст] / Н. Н Безбородкина, С. В. Оковитый, М. В. Кудрявцева, О. В. Кирик, И. В. Зарубина, Б. Н. Кудрявцев // Цитология. - 2008. Т. 50, № 3. - С. 228-236.

5. Смолякова, В. И. Антиоксидантные эффекты тиофана при экспериментальном поражении печени тетрахлорметаном [Текст] / В. И. Смолякова, М. Б. Плотников, Г. А. Чернишова, И. С. Иванов, А. Е. Просенко, Н. В. Кандалинцева // Бюллетень сибирской медицины. 2010. - № 5. - C. 98-101.

6. Способ моделирования цирроза печени [Текст] / В. А. Мышкин и др. // Патент РФ на изобретение №2197018 по заявке 2000103880 от 20.01.2003.

7. Мышкин, В. А. Мочевыделительная функция и состояние антиоксидантной системы почек крыс при моделировании некоторых форм патологи совтолом-1 [Текст] / В. А. Мышкин, Д. А. Еникеев, Д. В. Срубилин, Д. М. Галимов // Фундаментальные исследования. - 2013. № 2. - С. 129-132.

8. Борисенко, В. Б. Динамика морфологических изменений холедоха, печени и других внутренних органов при моделировании механической желтухи в эксперименте [Текст] / В. Б. Борисенко, С. Г. Белов, Н. И. Горголь // Харківська хірургічна школа. - 2012. - № 1 (52). - С. 46-52.

9. Ахаладзе, Г. Г. Клинические стадии острого гнойного холангита [Текст] / Г. Г. Ахаладзе, Н. Ф. Кузоовлев, Г. Р. Сакеварашвили, Б. В. Пинегин, Г. Г. Татишвили, Р. М. Хаитов, Э. И. Гальперин // Анналы хирургической гепатологии. - 1997. - Т. 2. - С. 103-109.

10. Leung, Т. М. Эндотелиальная синтаза оксида азота как важный фактор при экспериментальном фиброзе печени [Текст] / T. M. Leung, G. L. Tipoe, E. C. Liong, 
T. Y. Н. Lau, M. L. Fung, A. A. Nanji // Сучасна гастроентерологія. - 2010. - № 5 (55). - С. 109-119.

11. Куценко, С. А. Механизмы цитотоксичности [Текст] / С. А. Куценко // Основы токсикологи. - 2003. T. 4. - C. 119.

12. Овнанян, К. О. Сравнительный ультраструктурный анализ цитопротекторного действия антиоксиданта на гепатоциты при токсическом циррозе печени [Текст] / К. О. Овнанян, К. Г. Карагазян, В. Х. Мамиконян, А. С. Маргарян // Токсикология. - 2009. - № 3. C. $255-260$.

13. Безбородкина, Н. Н. Взаимосвязь между содержанием гликогена в гепатоцитах и их размером в нормальной и цирротической печени крыс [Текст] / Н. Н. Безбородкина, А. А. Вахтина, Е. В. Байдюк, Г. С. Якупова, Б. Н. Кудрявцев // Цитология. - 2009. T. 51, № 5. - С. 417-427.

14. Губич, О. И. Вовлеченность антиоксидантной системы цАМФ и $\mathrm{Ca}^{2+}$ зависимых путей сигнальной трансдукции в реализации цитопротекторных свойств циклопентеновых простаноидов группы А в условиях индуцированного CCl4 повреждения гепатоцитов in vitro [Текст] / О. И. Губич, В. В. Мосиенко, Ф. А. Гималова, М. С. Мифтахоф, Ф. А. Лахвич, М. В. Шолу // Биохимия простагландинов группы А (обзор). Биохимия. - 2006. T. 71, № 3. - C. 293-304.

15. Байдюк, Е. В. Сравнительный анализ морфофункциональных показателей культуры гепатоцитов, выделенных из нормальной и патологически измененной печени крыс [Текст] / Е. В. Байдюк, А. П. Ширяева, Н. Н. Безбородкина, Г. А. Сакута // Цитология. - 2009. T. 51, № 10. - C. 797-805.

16. Джояшвили, Н. А. Генная терапия фактором роста гепатоцитов приводит к регрессии экспериментального фиброза печени [Текст] / Н. А. Джояшвили, Н. И. Калинина, И. Б. Белоглазова, 3. И. Цококлаева, П. И. Макаревич, Ю. Л. Перов, Е. В. Парферова, В. А. Ткачук // РЖГГК, Оригинальные иссследования. 2010. - № 4. - C. 22-28.

17. Гулько, Т. П. Морфологическая характеристика процессов повреждения, компенсации и приспособления в патологически измененной печени при воздействии $\mathrm{CCl} 4$ [Текст] / Т. П. Гулько, М. В. Драгулян, Е. Г. Дерябина, В. А. Кордюм, М. Ю. Левкив, Р. В. Бубнов // Фактори експериментальної еволюції організмів. - 2014. - Т. 15. C. 39-44.

18. Топчий, Н. В. Эссенциальные фосфолипиды выбираем оптимальный вариант? [Электронный ресурс] / Н. В. Топчий, А. С. Топорков. - Независимое издание для практикующих врачей, 2013. - Режим доступа: http://www.rmj.ru/articles_8536.htm

19. Назар, П. С. Зміни біохімічних показників та загального аналізу крові в осіб із алкогольним ураженням печінки [Текст] / П. С. Назар, О. І. Осадча, М. М. Левон // Буковинський медичний вісник. - 2012. - Т. 16, № 1 (61). C. $59-62$.

20. Гулько, Т. П. Моделирование цирроза печени у крыс линии Wistar разного возраста [Текст] / Т. П. Гулько, М. В. Драгулян, С. Е. Рымар, В. А. Кордюм, М. Ю. Левкив, Р. В. Бубнов // Факторы экспериментальной эволюции организмов. $-2013 .-$ Т. 12. - С. 111-114.

\section{References}

1. Babak, O. Ya. (2007). Problema fibrogeneza nealkogolnoy zhirovoy bolezni pecheni. Suchasna gastroenterologIya, 4 (36), 4-10.

2. Lazarevich, N. L. (2004). Molekulyarnyie mehanizmyi progressii opuholey pecheni. Uspehi biologicheskoy himii, 44, 365-418.
3. Babak, O. Ya., Yarmyish, N. V., Panchenko, G. Yu. (2006). Mehanizmyi gepatoprotektornogo i toksicheskogo vliyaniya azota oksida. Suchasna gastroenterologiya, 5 (31), 76-84.

4. Bezborodkina, N. N., Okovityiy, S. V., Kudryavtseva, M. V., Kirik, O. V., Zarubina, I. V., Kudryavtsev, B. N. (2008). Morfometriya mitohondrialnogo aparata gepatotsitov normalnoy i tsirroticheski izmenennoy pecheni kryis. Tsitologiya, 50 (3), 228-236.

5. Smolyakova, V. I., Plotnikov, M. B., Chernishova, G. A., Ivanov, I. S., Prosenko, A. E., Kandalintseva, N. V. (2010). Antioksidantnyie effektyi tiofana pri eksperimentalnom porazhenii pecheni tetrahlormetanom. Byulleten sibirskoy meditsinyi, 5, 98-101.

6. Myishkin, V. A. (2003). Sposob modelirovaniya tsirroza pecheni. Patent RF na izobretenie № 2197018 po zayavke 2000103880 ot 20.01.2003.

7. Myishkin, V. A., Enikeev D. A., Srubilin, D. V., Galimov, D. M. (2013). Mochevyidelitelnaya funktsiya i sostoyanie antioksidantnoy sistemyi pochek kryis pri modelirovanii nekotoryih form patologi sovtolom-1. Fundamentalnyie issledovaniya, 2, 129-132.

8. Borisenko, V. B., Belov S. G., Gorgol N. I. (2012). Dinamika morfologicheskih izmeneniy holedoha, pecheni i drugih vnutrennih organov pri modelirovanii mehanicheskoy zheltuhi v eksperimente. HarkIvska hIrurgIchna shkola, 1 (52), $46-52$.

9. Ahaladze, G. G., Kuzoovlev, N. F., Sakevarashvili, G. R., Pinegin, B. V., Tatishvili, G. G., Haitov, R. M., Galperin, E. I. (1997). Klinicheskie stadii ostrogo gnoynogo holangita. Annalyi hirurgicheskoy gepatologii, 2, 103-109.

10. Leung, T. M., Tipoe, G. L., Liong, E. C., Lau, T. Y. H., Fung, M. L., Nanji, A. A. (2010). Endotelialnaya sintaza oksida azota kak vazhnyiy faktor pri eksperimentalnom fibroze pecheni . Suchasna gastroenterologiya, 5 (55), 109-119.

11. Kutsenko, S. A. (2003). Mehanizmyi tsitotoksichnosti . Osnovyi toksikologi, 4, 119.

12. Ovnanyan, K. O., Karagazyan, K. G., Mamikonyan, V. H., Margaryan, A. S. (2009). Sravnitelnyiy ultrastrukturnyiy analiz tsitoprotektornogo deystviya antioksidanta na gepatotsityi pri toksicheskom tsirroze pecheni. Toksikologiya, 3, 255-260.

13. Bezborodkina, N. N., Vahtina, A. A., Baydyuk, E. V., Yakupova, G. S., Kudryavtsev, B. N. (2009). Vzaimosvyaz mezhdu soderzhaniem glikogena $\mathrm{v}$ gepatotsitah $\mathrm{i}$ ih razmerom $\mathrm{v}$ normalnoy i tsirroticheskoy pecheni kryis. Tsitologiya, 51 (5), 417-427.

14. Gubich, O. I., Mosienko, V. V., Gimalova, F. A., Miftahof, M. S., Lahvich, F. A., Sholu, M. V. (2006). Vovlechennost antioksidantnoy sistemyi tsAMF i $\mathrm{Ca}^{2+}$ zavisimyih putey signalnoy transduktsii $\mathrm{V}$ realizatsii tsitoprotektornyih svoystv tsiklopentenovyih prostanoidov gruppyi A v usloviyah indutsirovannogo $\mathrm{CCl} 4$ povrezhdeniya gepatotsitov in vitro. Biohimiya, 71 (3), 293-304.

15. Baydyuk, E. V., Shiryaeva, A. P., Bezborodkina, N. N., Sakuta, G. A. (2009). Sravnitelnyiy analiz morfofunktsionalnyih pokazateley kulturyi gepatotsitov, vyidelennyih iz normalnoy i patologicheski izmenennoy pecheni kryis. Tsitologiya, 51 (10), 797-805.

16. Dzhoyashvili, N. A., Kalinina, N. I., Beloglazova, I. B., Tsokoklaeva, Z. I., Makarevich, P. I., Perov, Yu. L., Parferova, E. V., Tkachuk, V. A. (2010). Gennaya terapiya faktorom rosta gepatotsitov privodit $\mathrm{k}$ regressii eksperimentalnogo fibroza pecheni . RZhGGK, Originalnyie isssledovaniya, 4, 22-28.

17. Gulko, T. P., Dragulyan, M. V., Deryabina, E. G., Kordyum, V. A., Levkiv, M. Yu., Bubnov R. V. (2014). Morfologicheskaya harakteristika protsessov povrezhdeniya, kompensatsii i prisposobleniya $\mathrm{v}$ patologicheski izmenennoy 
pecheni pri vozdeystvii CCl4. Faktori eksperimentalnoyi evolyutsiyi organizmiv, 15, 39-44.

18. Topchiy, N. V., Toporkov, A. S. (2013). Essentsialnyie fosfolipidyi - vyibiraem optimalnyiy variant? Nezavisimoe izdanie dlya praktikuyuschih vrachey. Availavle at: http://www.rmj.ru/articles_8536.htm

19. Nazar, P. S., Osadcha, O. I., Levon, M. M. (2012). Zmini biohimichnih pokaznikiv ta zagalnogo analizu krovi $\mathrm{v}$ osib iz alkogolnim urazhennyam pechinki. Bukovinskiy medichniy visnik, 16/1(61), 59-62.

20. Gulko, T. P., Dragulyan, M.V., Ryimar, S. E., Kordyum, V. A., Levkiv, M. Yu., Bubnov, R. V. (2013). Modelirovanie tsirroza pecheni u kryis linii Wistar raznogo vozrasta. Faktoryi eksperimentalnoy evolyutsii organizmov, 12, 111-114.

Драгулян Марія Валеріївна, кандидат біологічних наук, науковий співробітник, відділ регуляторних механізмів клітини, Інститут молекулярної біології та генетики НАН України, вул. Акад. Заболотного, 150 , м. Київ, 03143, Україна

E-mail: parus_major@ukr.net

Гулько Тамара Павлівна, молодший науковий співробітник, відділ регуляторних механізмів клітини Інститут молекулярної біології та генетики НАН України, вул. Акад. Заболотного, 150, м. Київ, 03143, Україна

E-mail: ftp 2002@ukr.net

Кордюм Віталій Арнольдович, доктор біологічних наук, завідувач відділу, Член-кореспондент НАН України, академік АМН України, професор, відділ регуляторних механізмів клітини, Інститут молекулярної біології і генетики НАН України, вул. Акад. Заболотного, 150, м. Київ, 03143, Україна

E-mail: v.kordium@gmail.com

Бубнов Ростислав Володимирович, кандидат медичних наук, лікар ультразвукової діагностики

Клінічна лікарня «Феофанія», вул. Акад. Заболотного 21, м. Київ, 03680, Україна

E-mail: rostbubnov@gmail.com

Дерябіна Олена Григорівна, кандидат біологічних наук, старший науковий співробітник, завідувач відділу, відділ генних технологій, ДУ "Інститут генетичної та регенеративної медицини" НАМН України, вул. Вишгородська, 67, м. Київ, 04114, Україна

E-mail: oderyabina@gmail.com

\title{
УДК 574.2
}

DOI: 10.15587/2313-8416.2014.28956

\section{АЛЛЕЛОПАТИЧЕСКАЯ АКТИВНОСТЬ ЛИСТОВОГО ОПАДА ДРЕВЕСНЫХ РАСТЕНИЙ, ПОЧВЫ И КОПРОЛИТОВ В ПАРКАХ Г. ДНЕПРОПЕТРОВСК}

\author{
() А. І. Крючкова, Ю. Л. Кульбачко
}

В работе рассматривается влияние аллелопатических свойств опада древесных растений $u$ трофометаболической деятельности дождевых червей (Luтbricidae) на аллелопатические свойства почвы под древесными породами Acer platanoides L., Aesculus hippocastanum L., Ulmus minor Mill. в парках 2. Днепропетровск. Установлено, что трофометаболическая деятельность червей положительно влияет на аллелопатический статус почв.

Ключевые слова: аллелопатические свойства, копролиты дождевых червей, почва, парковая зона, листовой опад.

The article examines the impact of leaf litter allelopathic properties and earthworms trophy metabolic activity of earthworms (Lumbricidae) on the soil allelopathic properties under the Acer platanoides L., Aesculus hippocastanum L., Ulmus minor Mill. In the Dnepropetrovsk parks. It was established that earthworms trophy metabolic activity positively influenced on soils allelopathic status.

Keywords: allelopathic properties, coprolites of earthworms, soil, park, leaf litter.

\section{1. Введение}

Процессы почвообразования в современном промышленном городе с развитой транспортной инфраструктурой находятся под сильным влиянием антропо-техногенного прессинга, вносящего коррективы в процессы жизнедеятельности, как растительных организмов, синтезирующих органическое вещество, так и почвенных животных [1-6]. В связи с тем, что почва в городских условиях служит накопителем полютантов с их последующей медленной биотрансформацией, то еe аллелопатические свойства могут не только служить в качестве экологического маркера в урбаноценозах, но и характеризовать процессы детоксикации полютантов, которые в нее поступают разными путями, в том числе и благодаря опаду, который метаболизируется почвенной фауной. 